\title{
"The Real Thing": Election Campaigns and The Question of Authenticity in American Film and Television
}

\author{
GREGORY FRAME
}

This article examines the concept of authenticity in American politics through its construction and representation in fictional election campaigns in film and television. This article will posit The Candidate (1972), Tanner '88 (1988), Wag the Dog (1997) and The West Wing (19992006) as crucial sites of popular cultural critique of this aspect of the electoral process: The Candidate as a damning critique of television's influence, Tanner ' 88 as a satirical take on campaign films in the Reagan era, Wag the Dog as a savage indictment of spin-doctoring during Clinton's presidency, and The West Wing's attempt to rescue the process through the construction of an "authentic" political candidate. This involves close textual analysis of the four examples identified, examining the contrasting visual styles, strategies and tones. The textual discussions will not take place in isolation, however: this article will chart the simultaneous developments in realworld electoral politics, with particular focus on the influence of the media in the election campaigns contemporaneous with the fictional examples discussed. The article charts a shift in the representation of political authenticity, from a cynical attitude towards its possibility in the I 970 s, to an uncomplicated reversion to traditional markers of this elusive concept in the 2000 s.

\section{INTRODUCTION: AMERICAN POLITICS AND AUTHENTICITY}

... the search for political authenticity, the never-ending quest to find the real leader and true person behind the crafted image [is the] dominant telos in American political discourse. $^{\text {. }}$

Authenticity is an ancient concept, a Platonic ideal rooted in classical ideas about existential being. It stems from the notion that, according to Janis Edwards, "nothing fake can be good, and nothing good can be fake."

Department of Film and Television Studies, University of Warwick. Email: g.r.frame@warwick. ac.uk.

I Shawn J. Parry-Giles and Trevor Parry-Giles, Constructing Clinton: Hyperreality and Presidential Image-Making in Postmodern Politics (New York: Peter Lang, 2002), I 25.

2 Janis L. Edwards, "Presidential Campaign Cartoons and Political Authenticity," in Robert E. Denton, ed., The 2008 Presidential Campaign: A Communication Perspective (Plymouth: Rowman and Littlefield Publishers, 2009), I9I-209, 194. 
Shawn Parry-Giles and Trevor Parry-Giles suggest that, in Platonic understanding, there was a "loathing and anxiety about the unreal," such that "the inauthentic became unethical and virtue was conjoined with authenticity to define the appropriate standards of human behavior and communication." 3 As evidenced by the significance of partisan newspapers in nineteenth-century electioneering, US politics and the delivery of its messages has always necessarily been contingent upon a process of mediation and, as such, the search for authenticity has long been a preoccupation. ${ }^{4}$ Because most people will never actually know, or even meet, the men and women that lead them, the public is inevitably reliant upon mediated constructions to achieve something approaching a meaningful proximity to, and knowledge of, the characters of politicians. As demonstrated by suggestions that Mitt Romney's campaign for the US presidency in 2012 was ideologically hollow, of indeterminate or suspect motive, the urge to peel back the constructed facade to expose the politician's undiluted, "authentic" essence is as powerful as it has ever been. ${ }^{5}$

Indeed, some have suggested that the search for authenticity has grown more fevered in the contemporary moment. As author and journalist Stephen Poole argued, anxiety about inauthenticity has been exacerbated by a combination of globalization, the economic dominance of multinational corporations, and the inexorable rise of digital technologies since the 1990s. ${ }^{6}$ Applying such arguments to contemporary politics, in an age of twenty-four-hour rolling news,

3 Parry-Giles and Parry-Giles, I 22.

${ }^{4}$ For a broad view of this history see Ronald Lora and William H. Longton, eds., The Conservative Press in Eighteenth- and Nineteenth-Century America (Westport, CT: Greenwood, 1999).

5 Eugene Robinson argued that Romney's wealth precluded him from being an authentic presence on the campaign trail, as it rendered him incapable of identifying with ordinary people and coming across as a "real person." Eugene Robinson, in The Washington Post, 2 March 20I2, at www.washingtonpost.com/opinions/the-authentically-inauthentic-mittromney/2012/03/or/gIQAP 5 BalR_story.html, accessed April 2012. Romney's infamous, secretly filmed, comments that $47 \%$ of Americans automatically vote for the Democrats because they think they are entitled to government handouts confirmed to many that Romney was a typical politician who said one thing in public and another in private. The implications of these ideas and incidents are part of what this article looks to establish about political authenticity.

6 Stephen Poole, "Why Are We so Obsessed with the Pursuit of Authenticity?", New Statesman, 7 March 2013, at www.newstatesman.com/culture/culture/2013/03/why-arewe-so-obsessed-pursuit-authenticity, accessed March 2013. Much of Poole's argument appears influenced by Jean Baudrillard's infamous intervention in $198 \mathrm{I}$, in which he argued that any distinction between the "real" and the "represented" had collapsed as a result of mediation and manipulation. It is arguable that the rise of digital technology, whereby the relationship between the signifier and the signified has become even more eroded, has provoked a similar crisis of authenticity. See Jean Baudrillard, Simulacra/ Simulation (Ann Arbor: University of Michigan Press, 1994). 
the Internet, and YouTube, and in an environment in which images are constantly recontextualized and repurposed, the "aura" that might once have hung around public figures given their infrequent appearances in the ordinary citizen's everyday life is lost amidst a miasma of constant representation, mediation and remediation. However, while Poole might be correct in saying there is something specific about this contemporary crisis, the historical consideration and investigation of authenticity reveals many continuities with the past.

Concern about inauthenticity in culture appears to accompany most advances in technology. This worry was given perhaps its most famous expression in the modern period by Walter Benjamin, who lamented the loss of the original artwork's "aura" when reproduced by technological means. ${ }^{7}$ For Benjamin, humanity's ability to produce facsimiles of artworks inevitably eroded the distinction between the genuine and the imitation, further obscuring our access to the real thing. In I991, immediately prior to the explosion of digital technologies and the rise of the Internet, Charles Taylor argued that the impact of technology as a mediator of everyday experience resulted in a crisis of authenticity, "a loss of resonance, depth, or richness in our human surroundings." As Plato, Benjamin and Taylor suggest, the yearning for authenticity is not new. Indeed, it could be argued that, from newspapers to radio, cinema and the newsreel, through television, and now the Internet, how political authenticity is constituted has shifted, but what constitutes political authenticity has remained largely the same: it is the fundamental desire to know that, beneath the constructed politician, there exists a real person, with a stable identity and a core set of beliefs to which they remain wedded (something of which Romney spectacularly failed to convince the public). Therefore, rather than assert the falsehood that the search for the 'authentic' politician is a new preoccupation, this article will look to understand how this search has evolved in recent history, identify its origins, and explain how we arrived at our current state of affairs.

In order to illustrate this evolution, this article will compare and contrast developments in "real" politics alongside explorations of authenticity in fictional representations of the electoral process in mainstream American films and television. Both mediums have rich traditions of representing politics, and their attitudes towards political authenticity demand further investigation as they provide popular cultural barometers of contemporary

7 Walter Benjamin, The Work of Art in the Age of Mechanical Reproduction (London: Penguin Books, 2008; first published 1936), 7.

${ }^{8}$ Charles Taylor, The Ethics of Authenticity (Cambridge, MA: Harvard University Press, I991), 6. 
conceptualizations of authenticity beyond the boundaries of traditional academic discourse. In this regard, the article conforms to Joanne Morreale's argument that "in today's post-literate world, it is imperative that we understand the subordination of the word to the image in political persuasion." "With this in mind, what function might these representations of election campaigns perform in wider formulations of the concept of "political authenticity"? This is not to suggest that concerns about inauthenticity in public life exist only because of the ways in which election campaigns are conducted, but merely to demonstrate that the media obsession with the spectacle of election campaigns makes them crucial sites of meaning if the development of the concept of "authenticity" in American politics is to be understood.

As Ian Scott argues, "the construction of the Hollywood election film has ... paralleled the growth in image and personality that has developed significantly over time, but particularly since $1975 . "{ }^{\circ} \circ$ This article looks to establish the contours of this evolution, demonstrating how this critique has played itself out in an aesthetic sense, through closer attention to the visual dynamics of the texts themselves. The case studies chosen reflect this process: The Candidate (Michael Ritchie, 1972), reacting to the power television had acquired in the preceding decade, suggests the demands of a televised election campaign transforms the "authentic" political candidate into a packaged consumer product; Tanner ' 88 (Robert Altman, I988), somewhat resigned to this state of affairs, satirizes (amongst other things) the glossy, seductive Reagan-era campaign film but suggests that any attempt a candidate makes to separate themselves from this process is futile; Wag the Dog (Barry Levinson, 1997), a product of the Clinton era's preoccupation with "spin," takes the process to its logical conclusion by suggesting that, in this environment of media manipulation, authenticity is impossible because everything is a stage-managed illusion. The West Wing (1999-2006) is rather different: in keeping with the programme's challenge to widespread cynicism about contemporary politics, it reverts to an older attitude towards the individual and the political system established in American cinema by Frank Capra, revisiting the notion that the exceptional person (Congressman Matt Santos, played by Jimmy Smits) can rescue the process from media influence. ${ }^{11}$ All four texts respond to,

9 Joanne Morreale, The Presidential Campaign Film: A Critical History (Westport, CT: Praeger, 1993), xi.

10 Ian Scott, American Politics in Hollywood Film (Edinburgh: Edinburgh University Press, 2000), 68.

${ }_{11}$ The origins of film and television's search for authenticity in politics arguably lie in Frank Capra's films produced during the Great Depression. Mr. Smith Goes to Washington (1939) and Meet John Doe (194I) established a populist pattern: while individuals working within the system tend to be corrupt and self-serving, the system itself was a benign entity merely searching for a figure of exceptional character to return it to its righteous path. Both films 
critique and question changes in the style and presentation of American electoral politics in the periods in which they were produced: because of this historical dimension, I will present my textual analysis alongside discussion of developments in the conduct of actual election campaigns, particularly through the campaign films produced for, or by, presidential candidates. ${ }^{12}$ This will demonstrate the extent to which the fictional examples I discuss have responded to changes in "real" politics. More fundamentally, however, this approach will demonstrate the extent to which the definition of political authenticity remains largely consistent despite the distinct challenges it faces from different sources, particularly the changing means by which the electoral and political processes are represented, packaged and consumed through mass media. This combined approach is essential in order to sketch the history of, and criticism surrounding, authenticity in election campaigns in this period.

\section{THE I960S AND I970S: TELEVISION, THE CANDIDATE AND THE ELECTORAL PROCESS}

Television has had an overwhelming influence on the development, construction and consumption of electoral politics in the US, changing expectations of what candidates should (and could) look and sound like. ${ }^{\mathrm{I}}$ Indeed, "television ...

are concerned in one way or another with the issue of authenticity: Mr. Smith and Meet John Doe demonstrate how the folksy simplicity of its protagonists is exploited by the political establishment to disguise their nefarious behind-the-scenes machinations. In keeping with Capra's populist credentials, Smith and Doe, emerging from outside the political machine, possess the unvarnished quality that enables them to wrest control from these malignant forces, and reassert values of truth, honesty and integrity in American politics. Capra picked these ideas up in his later State of the Union (1948), in which Grant Matthews (Spencer Tracy), an industrialist picked to run for President, attempts to project authenticity by sticking to his beliefs rather than bowing to the wants of the party machine. The process ultimately defeats him, however, and he withdraws his candidacy. The contours of Capra's approach to American politics are explored in greater detail in Giuliana Muscio, Hollywood's New Deal (Philadelphia: Temple University Press, 1996); Jeffrey Richards, "Frank Capra and the Cinema of Populism," in Bill Nichols, ed., Movies and Methods (London: University Press, 1976), 65-77; Wes D. Gehring, "Pushing the Capra Envelope: Hero," Journal of Popular Film and Television, 23 (Spring 1995), 36-43; Charles Lindholm and John A. Hall, "Frank Capra Meets John Doe: Anti-politics in American National Identity," in Mette Hjort and Scott Mackenzie, eds., Cinema and Nation (London: Routledge, 2000), 34-42; Brian Neve, Film and Politics in America: A Social Tradition (London: Routledge, I992), 28-54.

${ }^{12}$ It is important to note the obvious differences between the four texts chosen-The Candidate and Wag the Dog are feature films, Tanner ' 88 a miniseries, and The West Wing a long-running serial drama. The possibility for a television show to develop depth and character over a period of time is obviously greater than for a stand-alone film.

13 Wide-ranging analysis of the evolution of the relationship between television and politics can be found in Robert MacNeil, The People Machine: The Influence of Television on 
made the personality of the candidate central: his quirks, hair style, skin color, voice tone, and apparent sincerity" rendered as important as "themes and programs." " I In essence, although it had been preceded by the newsreel and the radio (which both demanded similar qualities), television provided the final confirmation that the ability to perform for cameras had become a fundamental aspect of electoral politics. ${ }^{15}$ As suggested by Robert MacNeil, the ability to grasp complexity and immensity became secondary to the need to be articulate and expressive on television, firm emphasis being placed on "the appearance of competence rather than the fact of it." ${ }^{16}$ Essentially, the politician needed to be able to "act" in the theatrical sense of the term. As Stella Bruzzi argues, "to try to enforce the distinction between the 'real' person and the performance is futile; the politician is necessarily performative." ${ }^{17}$ Paradoxically, the ability to perform authenticity in the mediatized age becomes fundamental because, as Murray Edelman argues, "Inauthentic performance creates deep ambivalence in the public. It generates profound scepticism about political promises and accomplishments." ${ }_{18}$ It is interesting to note that, despite differing approaches to the subject, political scientists, film scholars and cultural historians broadly agree that the politician is a performative entity, and politics a performative act.

The centrality of performance in projecting political authenticity is confirmed by the contrasting fortunes of Presidents John F. Kennedy and Richard Nixon, who have come to embody the distinction between the

American Politics (London: Eyre \& Spottiswoode, 1970); Sig Mickelson, From Whistle Stop to Sound Bite: Four Decades of Politics and Television (London: Praeger, 1989); Roderick P. Hart, Seducing America: How Television Charms the Modern Voter (Oxford: Oxford University Press, 1994). Furthermore, Raymond Williams's suggestion that the massmediated performance fundamentally altered a society used only to occasional encounters with dramatic or theatrical performance is an instructive one in relation to electoral politics. Raymond Williams, Television: Technology and Cultural Form (London: Fontana, 1974), I-25.

${ }^{14}$ Theodore White, America in Search of Itself: The Making of the President 1956-1980 (London: Jonathan Cape, 1983), 167.

is According to MacNeil, Franklin D. Roosevelt's "Fireside Chats" proved crucial to his reelection in 1936. Opposed by $90 \%$ of newspapers, Roosevelt employed the radio as a means of cultivating an intimate, personal relationship with the electorate. Of course, the development of this relationship did not occur automatically-Roosevelt placed great emphasis on honing his performance for the radio, training his voice and perfecting his timing as he sought an affective (as well as rhetorical) relationship with the electorate. See MacNeil, I3 I; and Timothy Raphael, The President Electric: Ronald Reagan and the Politics of Performance (Ann Arbor: The University of Michigan Press, 2009), 93.

${ }_{16}$ MacNeil, I 40, my emphasis.

17 Stella Bruzzi, New Documentary, 2nd edn (London: Routledge, 2006), i 84.

${ }^{18}$ Murray Edelman, Constructing the Political Spectacle (Chicago: The University of Chicago Press, 1988), 59. 
apparently bona fide and the counterfeit in American electoral politics, arguably as a result of television's influence. ${ }^{19}$ Although Nixon was deemed to have adapted well to the demands of the new medium, rescuing his political career with the famous "Checkers speech" in September 1952, it has become received wisdom that it was his later, inadequate performance in the 1960 televised presidential debates that cost him a very close election. ${ }^{20}$ The differing reactions to the two candidates from radio listeners and television viewers suggests that Nixon suffered a performative failure on the visual medium: while his rhetorical skills sufficed to win the debate for those listening on the radio, according to Theodore White, his "clean, masculine" quality was "transmogrified" on television, making him appear glowering and heavy. ${ }^{21}$ As Eugene Patterson suggested of the Nixon-Kennedy debate, television "makes Kennedy look forceful. It makes Nixon look guilty." ${ }_{22}$ Kennedy, by contrast, appeared able to collapse the distinction between his true self and the being that appeared on television.

1960 was just the beginning. As Martin Plissner notes, by 1963 "television had overtaken newspapers as the principal source of public information about 'what's going on in the world today." ${ }_{23}$ However, its influence was not viewed by everybody as entirely benign. Writing only a year after Kennedy's election, Daniel Boorstin argued that American politics had become nothing but a series of "pseudo-events": carefully stage-managed photo opportunities lacking in spontaneity, their value centred on the extent to which they are "newsworthy," rather than "real." ${ }^{4}$ As much as it had been heralded as a further evolutionary leap in bridging the gap between politicians and the electorate, television's artificiality generated profound cynicism about its influence. Although its impact did not call off the search for authenticity, television's pervasiveness and power were deemed simultaneously seductive and suspect.

19 Away from the media spotlight, it would appear obvious who is the more "authentic" candidate: while Kennedy was part of an extraordinarily wealthy family with connections in Washington, DC, and benefited from his father's largesse in his campaigns for the House of Representatives and the Senate, Nixon, whose father was a service station owner and a grocer, was a self-made man from a very ordinary background.

${ }^{20}$ MacNeil, $126-30$.

${ }^{21}$ White, quoted in ibid,, 138.

${ }^{22}$ Quoted in Alan Schroeder, Presidential Debates: Forty Years of High-Risk TV (New York: Columbia University Press, 2000), 99. This is a notion further explored by Umberto Eco, who analysed Nixon's televised speech from 30 April 1973 (in which he denied any personal involvement in the Watergate Scandal), to demonstrate how the camera's capturing of the president's facial tics revealed that he was lying. Umberto Eco, "Strategies of Lying," in Marshall Blonsky, ed., On Signs (Oxford: Blackwell, i 985), 3-I I.

${ }^{23}$ Martin Plissner, The Control Room: How Television Calls the Shots in Presidential Elections (New York: The Free Press, I 999), 3.

${ }^{24}$ Daniel Boorstin, The Image: A Guide to Pseudo-Events in America (New York: Atheneum, 1985), II. 
This suspicion is manifest in Michael Ritchie's The Candidate, a damning indictment of the superficial, image-centred nature of campaigning in the television age. ${ }^{25}$ Young, idealistic public-interest advocate Bill McKay (Robert Redford) is implored by Washington politicos to run for a Senate seat in California against the entrenched incumbent, Crocker Jarmon (Don Porter). Despite his interests in civil rights and combating poverty, McKay's credentials as an authentic presence in the campaign are initially cast into doubt by his ancestry: he is the son of governor John McKay (Melvyn Douglas), and is therefore part of the machine of mainstream politics that has been deemed inauthentic. Despite using his name as brand recognition to cruise to nomination (and therefore risk being cloaked in the pall of inauthenticity), the rationale behind McKay's candidacy is that the knowledge that he will almost certainly lose will enable him to transcend the stagemanaged circus of the modern political campaign by voicing opinions that would not otherwise get a hearing. He will, in a sense, be permitted to present his authentic self, differentiate himself from his politician father, and not become trapped in the endless cycle of pseudo-events deemed necessary to win elections. However, his candour gains traction with an electorate disenchanted with the contrived nature of contemporary politics. As victory becomes a possibility, his campaign staff sand down his more incendiary attitudes, and "repackage" him as an electable moderate, now capitalizing on his position within a potential political dynasty to sell him as the inheritor of his father's mantle.

The process of constructing the modern candidate is foregrounded: there are scenes showcasing body language coaching, make-up, the set-up of a photo opportunity in his home to create the appearance of domestic serenity (when in reality his candidacy has resulted in the breakdown of his marriage), and the recording of a television advertisement. While editing some campaign material, McKay's staff are much more enthused by scenes of him throwing a football around and shaking hands, looking confident, strong and Kennedyesque (emphasizing another political dynasty), than by footage

${ }^{25}$ It is important to acknowledge that this cynicism was not new - The Best Man (Franklin J. Schaffner, 1964), based on Gore Vidal's play, examines the seamy underbelly of the nomination process in American politics, exposing the lengths to which politicians will go in order to win power. It is crucial to note, however, that the film (and play) take aim at the process itself, rather than the media's influence upon it, suggesting that cynicism regarding the media's influence had not reached the saturation levels they would by the early I 970 . As Bruce Schulman argues, in the I970s "Americans developed a deeper, more thorough suspicion of the instruments of public life and a more profound disillusionment with the corruption and inefficiency of public institutions," a feeling of disenchantment expressed clearly in The Candidate. Bruce Schulman, The Seventies: The Great Shift in American Culture (New York: Free Press, 2001), xv. 
where he outlines his health care policies in a hospital waiting room for a group of disgruntled and indifferent mothers caring for their screaming babies. Essentially, the successful performance of familiar iconography trumps the stumbling, but noble, effort at substantive debate; looking good on television is all that matters. The film suggests that the political machine reduces the previously unique individual "Bill McKay" to nothing more than another political cipher; as a newsreader asserts, "the voters are being asked to choose McKay like they choose laundry detergent." McKay's apparently genuine concerns for social issues such as poverty and unemployment are whittled down to a five-point plan and a stump speech, repeated ad nauseam. The Candidate demonstrates vividly how the authentic individual is remorselessly eroded by the influence of his advisers and the media, until there is nothing but an artificially constructed commodity.

The Candidate's representation of the televised debate explores this problem. McKay's attempt to engage in a proper discussion with Jarmon is hamstrung by the rules, which distil the candidates' responses to a series of soundbites. The film renders this breakdown of the "real" individual visually explicit: during the debate, the seated McKay is offered initially to the audience at only one remove, mediated through the film's camera. In order to demonstrate McKay's transformation into a media product, the image shifts to show him only through the viewfinder of the camera in the debate studio, mediating him even further; he has gone from "real" person to televised image. At one point, McKay's image is superimposed over Jarmon's, rendering the two candidates indistinguishable: McKay has become a carbon copy of the very thing to which his candidacy was opposed.

The Candidate argues that the impact of television on the electoral process is a devastating one, confirming Roderick Hart's suggestion that "because television manufactures everything, it believes in nothing." ${ }^{26}$ The film's conclusion reaffirms McKay's inability to hold on to his individuality in this environment: the hollow, insubstantial performance is seductive enough to win the election, but his policies and principles have been so undermined by the demands of the media, that he has no idea what to do with his new political capital. As he rather impotently asks his campaign manager at the film's conclusion, "What do we do now?" the infamous line which emphasizes the system's successful erosion of his agency, dynamism and independence. Unlike the later Primary Colors (Mike Nichols, 1998), which was naive enough to suggest that "the bullshit stops" after the campaign is over, Howard Hampton argues that "The Candidate not only saw through the bullshit,

${ }^{26}$ Hart, Seducing America, 13. 
but also saw through the ever-present notion that bullshit is all there is." ${ }_{27}$ It is clear that The Candidate defines authenticity as a matter of ideology: McKay's claim to it came from what he purported to believe before the campaign. However, these beliefs became so marginalized by the campaign's privileging of image and personality that by the end McKay has forgotten why he ran for office in the first place. By the film's conclusion any claim McKay had to authenticity has evaporated entirely; the media-managed, packaged politician is all that remains.

\section{THE I980S: TANNER ' 88 AND THE CAMPAIGN FILM IN THE REAGAN ERA}

Robert Altman's Tanner ' 88 represents an evolution in the attitude towards electoral politics. The miniseries is even more disillusioned with mediatized politics than The Candidate, and has a caustic tone comparable to much of Altman's earlier work, such as The Long Goodbye (1973), California Split (1974) and Nashville (1975). ${ }^{28}$ As Robin Wood suggested of Altman's dominant narrative model, "the protagonist embarks on an undertaking he is confident he can control; the sense of control is progressively revealed as illusory; the protagonist is trapped in a course of events that culminate in disaster (frequently death)." ${ }^{29}$ Chronicling the spectacularly unsuccessful attempt by fictional Congressman Jack Tanner (Michael Murphy) to win the Democratic Party's presidential nomination while staying true to his beliefs and maintaining control of his image, Tanner ' 88 conforms largely to this pattern. However, in order to address these issues, Tanner ' 88 audaciously mixes the "real" and the fictional: Tanner runs for President alongside actual presidential candidates like Pat Robertson, Bob Dole and Gary Hart, who make appearances. Tanner ' 88 is, as Morreale argues, a satire of both the political process and the techniques by which it is represented. ${ }^{30}$ As

${ }^{27}$ Howard Hampton, "See How They Run," Film Comment, 44, 5 (2008), 30-34, 3 I.

${ }^{28}$ However, it is telling that Altman, an auteur of the New Hollywood in the I970s, would retreat to the smaller confines of cable television in the following decade during a period in which American cinema became considerably more conservative: the home of explicit critiques of American politics and society was no longer the feature film (as it had been in the previous decade), but the documentary and the television mini-series.

29 Quoted in Christian Keathley, "Trapped in the Affection Image: Hollywood's Post Traumatic Cycle (1970-1976)," in Thomas Elsaesser, Alexander Horwath and Noel King, eds., The Last Great American Picture Show: New Hollywood Cinema in the Ig7os (Amsterdam: Amsterdam University Press, 2004), 293-308, 297.

30 Joanne Morreale, “Tanner ' 88 ," in Gary Edgerton and Jeffrey Jones, eds., The Essential HBO Reader (Lexington: The University Press of Kentucky, 2008), 103-1 5, I09. 
Altman noted, "we broke into new form. We used a mix of drama and comedy and reality and satire, fiction and non-fiction." ${ }_{31}$

Emerging at the end of the Reagan era, Tanner ' 88 engages with the contemporary suggestion that, with a former Hollywood actor in the White House, American politics has been irrevocably changed, and entirely subsumed by the illusory qualities of the image. ${ }^{32}$ Reagan's campaigns for President culminated in the saccharine film Morning in America (1984), which was shot on $35 \mathrm{~mm}$ and openly modelled on advertisements for companies like Pepsi Cola and McDonald's. It sold the appeal of Reagan like a commodity, invoking images of America's past in a nostalgic, soft-focus dream, featuring images of families on lawns protected by white picket fences, a montage of generations of citizens raising the American flag, and one particularly sentimental display of a white wedding, where the couple leave the church in slow motion and confetti is thrown as they smile ecstatically for the camera. After George H.W. Bush's similarly emotional appeals in 1988 , in which a small child was shown running into the future President's arms in slow motion, Morreale notes that "polls revealed that the majority of voters were disenchanted with the highly produced, emotion-based appeals that characterized the past two Republican elections." ${ }_{33}$ Visual and rhetorical excess had now become markers of inauthenticity.

The primary focus of Tanner ' 88 's critique of political authenticity centres on Tanner's campaign film. Directed by one of his campaign staff, Deke, and played for a focus group of voters before the New Hampshire primary election, it is the definition of inauthenticity. Tanner's film employs similar rhetorical devices to the campaign films of Reagan and Bush: archive images from eradefining American history such as Pearl Harbor, the presidency of John F. Kennedy and the Civil Rights movement rather arbitrarily associate Tanner with these moments in the recent past. ${ }^{34}$ Although this strategy worked for Bush as he triumphed at the polls, the reaction of the focus group in Tanner ' 88 is damning. Tanner's performance, which includes embarrassingly stilted direct-to-camera address, undermines his attempt to appear as a genuine "man of the people." The opening scene of the film shows the candidate shovelling snow from outside his front door, before retreating inside to take an apparently "unexpected" phone call (although the deliberately clunky performance and editing are clearly intended to

31 Ibid., 106-7.

32 Raphael, The President Electric, 2.

33 Like Bush's 1988 campaign film, Morreale argues that this recycling of archive footage ignores current problems, and "returns viewers to the nostalgic site of a former, successfully met challenge," whether or not the candidate had anything directly to do with this resolution. Morreale, 162.

34 Ibid., I 5 I. 
highlight the artificiality of such processes). Tanner is unable to perform authenticity.

When it becomes apparent that the focus group can see through the disingenuousness of this construct, the campaign staff attempt to turn an improvised rant from Tanner into a replacement film: frustrated by his inability to deliver his message because of the media demands of the modern campaign, Tanner explodes into an emotional speech about leadership, unaware that Deke is filming him from beneath the coffee table. His campaign staff are enthralled by the result. They think that capturing and broadcasting this unscripted diatribe (which appears all the more genuine because the image is distorted by the glass table through which it was captured) will enable them to deliver this uncomplicated, straightforward, "authentic" Tanner to the electorate, conforming to Parry-Giles and Parry-Giles's suggestion that, as authenticity becomes more elusive in an imagistic culture, "the political culture and its participants generate discourses that ostensibly erode the image and attempt to uncover the authentic or the real." 35 However, the attempt is a failure primarily because it has to be reinserted into the conveyor belt of campaign politics. Despite Tanner's demonstrable ability to articulate his principles passionately and honestly outside the glare of the media spotlight, the need to reappropriate and repackage it as campaign material paradoxically reveals "Tanner: For Real" to be artificial.

Tanner ' 88 is daring enough to question whether the "real" candidates in the 1988 election are any less artificial than the entirely fictional Jack Tanner. While The Candidate suggested that the authentic individual is undermined, and ultimately destroyed, by the influence of the media, Tanner ' 88 posits the notion that the very fact of mediation instantaneously undermines any candidate's claim to authenticity; Tanner is no more "real" or "fake" than the politicians he encounters. The programme also expresses profound doubt as to the ability of the modern candidate to transcend the media frenzy to maintain a sense of their true beliefs or real identity. Like McKay, Tanner is overwhelmed by the influences of his campaign managers and media advisers. By the end of each episode, Tanner is shown to be flummoxed by the chaos around him, a feeling captured by Altman's use of freeze-frame; unsure whether he is coming or going, Tanner's suspension in time is the stylistic equivalent of McKay's "What do we do now?" It is clear that Tanner '88's definition of what constitutes political authenticity is not all that different from that of The Candidate: it stems from political conviction. However, while The Candidate appears to suggest that authenticity is a concept that is lost gradually over the course of a media campaign, Tanner ' 88

35 Parry-Giles and Parry-Giles, Constructing Clinton, i 19. 
argues that the pursuit is doomed from the outset. Tanner's beliefs are ultimately meaningless because the means by which they will be presented - the media - will inevitably render them intangible, insubstantial, and inauthentic.

\section{THE I990S: WAG THE DOG, THE WAR ROOM AND INAUTHENTICITY IN THE CLINTON ERA}

Wag the Dog represents a further evolution in Hollywood's attitude to electoral politics. Whereas Tanner ' 88 reiterates the inability of the individual to transcend the influence of the media in an even more hyperbolic fashion than The Candidate, Wag the Dog appears entirely resigned to the artificiality of (post)modern politics: everything is a media-manufactured illusion, even war, as the President's media advisers attempt to distract from a sex scandal in the immediate run-up to the election by fabricating a conflict with Albania. Released in the weeks immediately preceding allegations that President Clinton had an affair with White House intern Monica Lewinsky, for a brief period Wag the Dog became, rather like The Thick Of $I t$ in the United Kingdom, the defining reference point whenever "real" politics begins to imitate its fictional counterparts. ${ }^{36} \mathrm{It}$ is clear, however, that the film's attitude towards the inauthenticity of American politics has its origins earlier in the Clinton presidency.

Ever since he became a candidate for President, Clinton was mired in controversy and scandal. He was seen, as Morreale suggests, as "a typical politician who 'wouldn't look you straight in the eye." ${ }_{37}$ As Jason Mast argues, there were two Bill Clintons that existed in the mind's eye of the electorate in 1992: one was the "hopeful, empathetic, inclusive, and brilliant" politician who won in November, and "the other seemed to treat the truth the way a grifter handles a deck of cards; he would play with it masterfully and deal you any hand you wanted." 38 In order to combat this, Clinton adopted two communicative strategies in an attempt to project an authentic image: his campaign film, The Man from Hope, sought to reposition him as a "warm, honest,

${ }^{36}$ In August 1998, as Clinton was due to testify under oath to Kenneth Starr's investigation into whether the president had had an inappropriate relationship with White House intern Monica Lewinsky, he ordered attacks on terrorist training camps in Sudan following the bombing of US embassies in Kenya and Tanzania. According to Tom Stempel, Clinton was immediately excoriated by the Republican Party and the press for " "wagging the dog.' The title of the film had become part of the language, and it was used to beat up on Clinton." Tom Stempel, "The Collaborative Dog: Wag the Dog (1997)," Film and History, 35, I (2005), 60-64, 63.

37 Morreale, I64.

${ }^{8}$ Jason L. Mast, The Performative Presidency: Crisis and Resurrection during the Clinton Years (Cambridge: Cambridge University Press, 2013), 43. 
plain-folks idealist," with recourse to his humble, rural upbringing, employing close-ups that allowed viewers access to his interiority, looking to project authenticity through transparency. ${ }^{39}$ The second, more directly relevant to Wag the Dog, was Clinton's decision to grant permission to a documentary team, including veteran of cinema vérité D. A. Pennebaker, to shoot behind the scenes on his 1992 campaign.

The resulting film, The War Room (1993), chronicles the efforts of Clinton's communications strategists, James Carville and George Stephanopoulos, as they wrestle with the media for control over the candidate's image, attacking his opponents, and dousing the flames of controversy surrounding Clinton's personal life. The War Room has become an example of what Shawn and Trevor Parry-Giles describe as "meta-imaging"; "the communicative act whereby political campaigns and their chroniclers publicly display and foreground the art and practice of political image construction." 40 Bruzzi argues that the film illustrates how "the mythologisation of [Clinton] is manufactured by spin doctors and their artful manipulation of the media." 41 The War Room explores this artifice, allowing us to gaze, Wizard of Oz-like, behind the curtain: the privileged backstage access offers the illusion that we might "get 'inside' ... to unmask the image and the 'real candidate'." ${ }_{42}$ In this environment, there appears to be an acceptance that the construction and management of the candidate's image is at least as important as the candidate's ideological positions, if not more so. In a sense, therefore, by foregrounding the processes of candidate construction and media manipulation, The War Room appears to suggest that knowing how the candidate is manufactured, and what purpose this process will ultimately serve, is what constitutes the "authentic" in postmodern politics: we may not "know" the candidate, but we can know how he was created.

However, it might be suggested that, by exploring the idea of "Bill Clinton" as a stage-managed construct created by image consultants, The War Room somewhat opened the door for a film like Wag the Dog to deliver the media-managed election campaign to its logical conclusion. Like Clinton in The War Room, the President in Wag the Dog is barely seen, but he is largely irrelevant in an environment in which the notion of the "authentic" and the "real" is constructed and manipulated by spin doctors, media advisers and Hollywood film producers. This notion is epitomized by the assertion of spin doctor Conrad Brean (Robert De Niro), "Of course there's a war, I'm

39 Ibid.

40 Shawn Parry-Giles and Trevor Parry-Giles, "Meta-Imaging, The War Room, and the Hyperreality of U. S. Politics," Journal of Communication, 49, I (I 999), 28-45, 28.

${ }^{41}$ Bruzzi, New Documentary, I72. $\quad 4^{42}$ Parry-Giles and Parry-Giles, "Meta-Imaging," 29. 
watching it on television!" While The Candidate and Tanner ' 88 posit the notion that the authentic self, normally centred on a politician's beliefs, is lost as a result of the media's emphasis on spectacle and personality, Wag the Dog suggests that the concept itself can be entirely manufactured. The producers coopt many of the markers of authenticity to ensure a veneer of "truth" to their conflict: the war footage shot in a Hollywood studio employs the cultural shorthand of the handheld camera to verify the footage's authenticity. ${ }^{43}$ However, the artificiality of this construct is foregrounded: the girl (Kirsten Dunst) running away from gunfire carries a cat that is added digitally in postproduction. The advisers manufacture a folk song to suit their purposes, undermining the genre's reputation for handmade, agrarian honesty, markers of authenticity in American culture. By the film's end, it is asserted that television has "destroyed the electoral process," and that the President's "89\% approval rating [is] based not on the events, but the spin given to those events."

Wag the Dog's conclusion appears to suggest that the media's impact on American politics has come full circle: where the politician's mastery of television was cultivated to establish intimacy with the electorate, now its ability to disguise problematic truths using these techniques is shown to be all-important. As Brian Neve argues, "The film suggests a hypodermic effect as much as a hegemonic struggle, with the manipulation being shown as total and untraceable." 44 What makes Wag the Dog so cynical is that the pliable masses ingest these images uncomplicatedly and without question. While The Candidate and Tanner ' 88 focus their ire on the electoral process, Wag the Dog arrives at the conclusion that American politics is entirely, as Hollywood producer Stanley Motss (Dustin Hoffman) suggests, "a pageant": a seductive, glamorous performance of familiar and reassuring markers of authenticity, repackaged along generic, iconographic and narrative lines.

THE 2000S: THE WEST WING, “THE OUTSIDER,” AND POLITICAL AUTHENTICITY

Born in the final years of Clinton's presidency, The West Wing, Aaron Sorkin's broadly liberal, defiantly optimistic vision of American politics and

43 This process of coopting the traditional markers of authenticity as a disguise for unpleasant policies and ideas is also explored in Bob Roberts (Tim Robbins, 1992), a mockumentary in which a Republican singer with designs on a seat in the Senate uses folk music, a genre associated with agrarian, homespun honesty, to sell his reactionary policies to the electorate, and disguise his corruption and mendacity.

${ }^{44}$ Brian Neve, "Frames of Presidential and Candidate Politics in American Films of the I 990s," The Public, 7, 2 (2000), i9-32, 27. 
the presidency, offered "a pointedly sunny weekly fable about the unassailable motives and all-too-human foibles of the nation's governing class which verges on the Capra-esque." ${ }^{45}$ The West Wing provided a counterpoint to the cynicism of the period, offering, as Janet McCabe suggests, "a glimpse of something better, something truer, nobler than the partisan sniping and hairsplitting arguments that plagued the final months of the scandal-ridden Clinton presidency and defined the disputed 2000 election." ${ }^{46}$ Unsurprisingly, the representation of the electoral process (the search for President Josiah Bartlet's successor dominates the final two seasons) is similarly buoyant, perhaps as a response to the programme's explorations of darker subjects as a result of 9/I I and its aftermath. Unlike the other examples discussed in this article and, indeed, other contemporary explorations of the electoral process like Man of the Year (Barry Levinson, 2006) and Swing Vote (Joshua Michael Stern, 2008), The West Wing reasserts the Capra-esque possibility that the exceptional (but ordinary) individual can transcend this whirling vortex of artifice and lies to project a convincing image of authenticity, built at least partially on that individual's inherent qualities and characteristics.

This "exceptional individual" is Congressman Matt Santos: Hispanic, working-class Texan, Gulf War veteran, and the first member of his family to attend college. Like Capra's heroes, Santos's claim to authenticity lies in his ordinariness. In its suggestion that this imbues him with innate qualities that facilitate a greater affinity with the public, The West Wing looks to enforce the distinction between the "real" and the "performative" politician. Whereas the other candidates in the programme attempt to perform authenticity (some more successfully than others), the construction of Santos suggests that he possesses intrinsic qualities that preclude him from needing to do so; he is not a construction, he is "the real deal." Whether or not this is in fact achievable, the concept of "the real deal" or "the real thing" is fundamental to the search for authenticity in politics: as Miles Orvell suggests, "when we call an experience or a thing 'the real thing,' we identify a quality of intensity that is otherwise lacking in the featureless background that constitutes the main

45 Chris Lehmann, "The Feel-Good Presidency: The Psuedo-Politics of The West Wing," in Peter C. Rollins and John E. O'Connor, eds., The West Wing: The American Presidency as Television Drama (Syracuse, NY: Syracuse University Press, 2003), 2 I 3-22, 2 I 5.

${ }^{46}$ Janet McCabe, The West Wing (Detroit: Wayne State University Press, 2012), 95-96. The programme did, however, respond to $9 /$ I I and the "war on terror" through changes in its visual style and tone. This is explored briefly in ibid., at 59-83; and throughout Shawn Parry-Giles and Trevor Parry-Giles's The Prime-Time Presidency: The West Wing and U.S. Nationalism (Chicago: The University of Illinois Press, 2006); and it forms the basis of chapter 4 of my own book The American President in Film and Television: Myth, Politics and Representation (Oxford: Peter Lang, 2014). 
hum of experience." 47 But what is it specifically about Santos that marks him out as authentic compared to his opponents, that separates him from this "hum," and is this really any different to the other artful, manipulative constructions of authenticity with which this article has already engaged? I will now proceed to discuss the two ways in which The West Wing achieves this: through distinguishing Santos from his opponents by establishing him as a political "outsider," and, concomitantly, through Santos's uncomplicated employment of old indicators of televisual liveness and transparency as markers of authenticity.

During the 2008 election season, West Wing writers were keen to point out the influence that Barack Obama had had on the fictional figure of Matt Santos. ${ }^{48}$ While much has been made of the candidates' racial backgrounds, and their separation from the white, Anglo-Saxon, Protestant males that had dominated the political landscape since the republic's inception, this seems to be red herring. ${ }^{49}$ Both were desperate to avoid being defined solely by this marker of identity (evidenced by Santos's desire to be viewed as "the American candidate" and not "the brown candidate," and Obama's conciliatory, unifying rhetoric where he sought to heal racial divides in his "A More Perfect Union" speech in March 2008). 50 A more compelling similarity is their cultivated status as "outsiders" to the political establishment, and the associated impact upon their ability to project authenticity.

Indeed, the 2008 presidential election could be termed the year of the "outsider," with candidates drawn from outside, or at least looking to position themselves as distinct from, "normal politics," particularly Barack Obama, John McCain and Sarah Palin. ${ }^{\text {I }}$ In essence, politicians cultivate the image

47 Miles Orvell, The Real Thing: Imitation and Authenticity in American Culture 1880-1940 (Chapel Hill: University of North Carolina Press, 1989), xvi.

${ }^{48}$ Jonathan Freedland, "From West Wing to Real Thing," The Guardian, 21 Feb. 2008, at www.theguardian.com/world/2008/feb/21/barackobama.uselections2008, accessed Aug. 2011 .

49 For an explication of the supposed "similarities" between Obama and Santos see Douglas Kellner, Cinema Wars: Hollywood Film and Politics in the Bush-Cheney Era (Chichester: Wiley-Blackwell, 2010), 37; a compelling and thorough investigation into the political problematics of the "post-racial" is developed in David A. Frank and Mark Lawrence McPhail, "Barack Obama's Address to the Democratic National Convention: Trauma, Compromise, Consilience, and the (Im)possibility of Racial Reconciliation," Rhetoric and Public Affairs, 8, 4 (2005), 57 I-93.

so Barack Obama, "A More Perfect Union," i 8 March 2008, at www.huffingtonpost.com/ 2008/03/18/obama-race-speech-read-th_n_92077.html, accessed Oct. 2013.

51 This was by no means a new strategy, as the "Outsider" construction has been consistently employed by candidates looking to challenge an entrenched establishment that has proved itself at best incompetent, and at worst untrustworthy: Jimmy Carter cultivated a populist, antipolitics image in 1976 in the aftermath of the Watergate scandal, while Ronald Reagan's antigovernment stance in 1980 to unseat Carter was cut from similar cloth. Much of 
of the "outsider" in order to differentiate themselves from "politics-as-usual," the status quo, to show that they will not remain wedded to a party platform or belief system that is outdated or broken. Although he was a Harvard-educated lawyer and one-term Senator, Obama placed great emphasis on a personal narrative that took him from Kenya to Chicago via Hawaii and Indonesia, citing his opposition to the invasion of Iraq as further evidence of his ability to stick to his beliefs despite party pressure..$^{22}$ Similarly, Palin's status as governor of Alaska positioned her almost as far from Washington, DC as it is possible to be and still be American. Her claim to authenticity, Edwards argues, "hinged on her simulation of authenticity as a bare-faced, unreconstructed representative of 'real America', presumably as in white, working-class, nonelite, red state America"; she was firmly positioned as distinct from the urban, Washington DC elite whose economic policies had resulted in financial meltdown. ${ }^{53}$ Straddling this divide was Republican nominee John McCain. Despite a long career in the Senate, McCain argued he was a "maverick" within the Republican Party who did not merely regurgitate the status quo. This strategy formed part of an ultimately failed attempt to distance himself from George W. Bush, whose popularity reached record lows in the autumn of 2008. ${ }^{54}$ McCain named his campaign bus the "Straight Talk Express," "linking the idea of 'the real' with candor and an absence of artifice." 55 As Shawn Parry-Giles argues, oppositional opinions, and a willingness to challenge the status quo, are crucial to a political candidate's ability to claim authenticity. ${ }^{56}$ Ultimately, however, this links with the idea suggested earlier that authenticity is wedded to ideological conviction: while Obama, McCain and Palin all constructed themselves as "outsiders," it was in their willingness to challenge conventional thinking, and "stick to their beliefs," that their appeal lay.

Santos's "outsider" status is grounded in a similar tendency to remain committed to an ideological core despite the pressure to toe the party line. While not entirely an "outsider" in the strictly Capra-esque sense of the term, he is indeed a maverick, demonstrating a willingness to cooperate with the Republicans if he believes in the mission, something entirely at odds with

Kennedy's appeal to the electorate in 1960 was grounded in the cultivation of a similar identity.

52 In October 2002, Barack Obama described any intervention in Iraq as a "dumb war."

"Transcript: Obama's Speech against The Iraq War," 2 Oct. 2002, at www.npr.org/templates/ story/story.php?storyld=99591469, accessed Oct. 2013.

53 Edwards, "Presidential Campaign Cartoons and Political Authenticity," 196.

54 This strategy is explored in Kate Kenski, Bruce W. Hardy and Kathleen Hall Jamieson, The Obama Presidency: How Media, Money and Message Shaped the 2008 Election (Oxford: Oxford University Press, 2010), 1 3-26.

ss Edwards, 196.

${ }^{56}$ Shawn Parry-Giles quoted by Edwards, 195. 
the deeply partisan environment in which he finds himself. He also believes passionately in addressing issues within American society that are ignored because of political prudence, particularly health care and education (both pet liberal projects that, until Obama's recent qualified success with the former, were routinely dismissed as doomed to failure). Although his pursuit of these platforms may alienate the party establishment, Santos places his beliefs before his career. When he is introduced at the start of the sixth season, he is entirely frustrated with the system: he wants to leave politics because he feels he can achieve more at a grassroots level by opening hospitals in Texas - as he suggests to Josh, "That's not a health care agenda. That's health care." He projects authenticity in the sense that his actions are not entirely defined by his desire for advancement: he actually believes in what he is doing.

Santos's authenticity is partly established through comparison with other candidates. Vice President Bob Russell (Gary Cole) is The West Wing's clearest example of what the programme perceives to be inauthentic: a candidate who is inextricably wedded to the party establishment and corporate elite in order to win the Democratic nomination. His policies are triangulated and carefully managed, he tells the same (bad) joke about the presidential seal in his stump speech on numerous occasions, and everything he says and does is poll-tested. He even gives out Russell-branded merchandise like letter openers and cup holders in a naked attempt to curry favour with prominent politicians, distracting from the fact that he has no original ideas or policies: his politics are rendered as disposable tat. In another of The West Wing's swipes at Bush, Russell wears cowboy boots in a ham-fisted effort to project an image of rural authenticity. Russell even has a cardboard cutout of himself as campaign merchandise, reinforcing the notion that he is exactly the kind of inauthentic politician churned out by the Washington machine. The programme goes so far as to suggest that there is no distinction between the replica and the "real" man: when Josh visits Russell campaign headquarters, he is surrounded by these counterfeit totems. One of Russell's staff tells Josh that the public love having photographs taken with the cardboard cutout; the fake Russell fulfils the same function as the real one. In Russell's case, the "real" is irrelevant. The West Wing is desperate to find the figure that will revive the dormant concept of authenticity in American politics. Santos appears to fulfil this yearning, The West Wing positioning him as the unique individual opposed to the cookie-cutter politician embodied by Russell. Indeed, as Santos himself says, "I want to win, but I want to do it without being another cardboard cutout."

Russell is the classic embodiment of the "Beltway" politician. The programme's yearning for authenticity appears to coalesce around the connotations of this term. The Beltway refers to the ring road that runs around 
Washington, DC, in many ways isolating the nation's politicians from the rest of the country. Josh apologizes for his earlier insistence that Santos campaign along establishment lines, turning his pursuit of the presidency into another “cookie-cutter Beltway hack-a-thon." Later, Santos's communications director Louise Thornton (Janeane Garofalo), acknowledging the substantial threat that their Republican opponent Arnold Vinick (Alan Alda) poses to Santos's chances because of his moderate ideological views and broad electoral appeal, urges Josh to adopt a new strategy by referring to him as "Beltway Arnie" because of his long career in the Senate. Indeed, as Vinick has his own claim to "outsider" status through his refusal to kowtow to the socially conservative wing of the Republican Party, the Santos campaign's attempt to reposition him as an establishment, "Beltway" figure is crucial. It is almost constructed as a term with which to smear an opponent: in The West Wing's formulation, "Beltway politicians" are those who compromise their principles in order to secure steady streams of campaign finance, only to pursue policies that are politically prudent, poll-tested and focus-grouped, and reinforce the status quo by not upsetting the political and corporate establishment. The Beltway is, in effect, everything that is inauthentic about American politics.

The West Wing's use of television in Santos's campaign performs a fundamental corollary to its establishment of the candidate as possessing an innate authenticity. As Morreale suggests, television "creates the impression of live, immediate, and transparent reproduction of the 'real,' and thus serves as a substitute for viewers' direct experience." 57 In this, The West Wing is rather oldfashioned, reasserting the centrality of the qualities for which television was celebrated upon its inception: liveness, intimacy, and immediacy. ${ }^{8}$ In relation to this, I will analyse Santos's primary campaign advertisement, performed and broadcast "live," as an example of this.

In "Freedonia," Santos's upstart campaign is struggling to make headway against the establishment figures of Russell and former vice president John Hoynes (Tim Matheson). A particular bugbear is the tone of the television advertisements, which Santos deems to be vicious, manipulative and degrading. He reserves specific ire for the introduction accompanying each advert, in which the candidate looks directly into the camera and tells the viewer that they approved the message to follow. Santos sees this for the ruse it is: the candidate speaking directly to camera in some way justifies the attacks upon opponents because it is supposedly his or her "authentic" voice. The West Wing

57 Morreale, "Tanner '88," 2.

58 Jason Jacobs, The Intimate Screen: Early Television Drama (Oxford: Oxford University Press, 2000). 
reveals this as a construct in later episodes when it shows Vinick recording this leader, going through several takes. This supposed guarantor of authenticity is then attached to any advertisement the campaign staff see fit, thereby nullifying the claim that the candidate has approved each and every word, and renders the claim to validity fraudulent.

Santos looks to shift his own campaign away from these manipulative games. He disdains the television spot Josh has put together for his campaign (the only one they can afford), in which a Santos staffer dresses up in a chicken suit and accuses the other candidates of being too cowardly to debate him. Santos dismisses the advert as "cheap" and jettisons it, instead marching down to the television studio to deliver his message live. He is framed in a medium shot, and speaks his piece frontally, directly to the camera, with no added graphics or gimmickry. Santos outlines briefly the reasons why he is running for President, but reserves special mention for the inadequacies of modern campaigning. He laments its dishonesty and lack of integrity; in essence, he bemoans the inauthenticity of a process that puts political pointscoring above policy, ideas and substantive debate. He goes on to say that he will not say anything about his opponents, or the issues at stake, "without saying it [him]self, right into the camera," attempting to cultivate an intimate, ingenuous relationship with the electorate. Santos will not hide behind the artifice of the media, and besmirch his opponent by proxy: his honesty will guarantee authenticity.

Unlike Tanner's "For Real" advertisement, whose unvarnished and improvised quality was diluted by its packaging for television, Santos is able to claim authenticity because his words are unprepared (none of his campaign staff know what he is going to say), and broadcast live, lending them a quality of immediacy absent from all other campaign advertisements. Although Santos's message is mediated, it demonstrates the extent to which The West Wing resorts to a common discursive construction of liveness as a supposed guarantor of authenticity; the rehearsed, scripted, and repeated communications from the other candidates are artificial in comparison. 59 Although the camera is not handheld, Santos's direct address, coupled with the unscripted, "live" nature of the broadcast, creates a "natural" and "human" feel. His closing statement, "I'm Matt Santos, and you better believe I approved this ad," uttered once and without opportunity for further takes, is crucial. Rather than deliver a rehearsed performance of authenticity, Santos's improvisation is an attempt to transmit his straightforwardness and conviction

59 The form, style and performance of authenticity here approximates what Paddy Scannell describes as "believability" in broadcasting. Paddy Scannell, Radio, Television and Modern Life (Oxford: Blackwell, i 996), i I I. 
through the television screen, to attain qualities of proximity and directness with the audience. Indeed, The West Wing's positive attitude towards the power of television suggests a reversion to the acceptance of its qualities as a medium of straightforward communication and transparency. Perhaps, given the bitter, furious tenor of election campaigns in the period in which The West Wing was produced, with the instantaneous blogging of rumour and scrutiny of the minutiae of the candidates' behaviour and appearance, the television appears benign, even truthful, by comparison. ${ }^{60}$ While a more cynical programme might look at this at one remove, and emphasize that Santos is capitalizing on discursive constructions of authenticity and truth - the live broadcast, the unrehearsed nature of his words - to achieve his goals, The West Wing unironically valorizes these as markers of authenticity. With very little evidence from wider culture to suggest it should, The West Wing manifests a desire to believe in the possibility of authenticity again: in both the person delivering the message, and the medium through which it is disseminated.

\section{CONCLUSION}

This article suggested at the beginning that, although election campaigns and political candidates have always been necessarily mediated constructions, as the media's influence on the electoral process has developed, the desire for authenticity has become more fevered as the possibility of its realization has grown more distant. By comparing fictional candidates in cinema and television with "real-world" developments in the political process, this article has demonstrated the ways in which popular culture has functioned as a crucial site of critique in response to this relationship, chronicling an attitude that grew considerably more pessimistic from the I970s to the I990s. However, while The Candidate, Tanner ' 88 and Wag the Dog chart the gradual death of authenticity in mediated politics, The West Wing asserts the possibility of its recovery through a reversion to older conceptualizations of the concept. With some variations in tone, all the examples discussed locate authenticity in ideological conviction. In its own way, each example responds to, and interacts with, specific changes in electioneering in the United States: increased cynicism about the influence of television, the style of campaign films, and the pervasiveness of "spin" appeared to render the pursuit of political authenticity an entirely futile one. However, despite the attitudes expressed in Wag the Dog

${ }^{60}$ Nicolle Wallace and Anita Dunn, "Electing the President 2008: The Insiders' View," in Doris A. Graber, ed., Media Power in Politics, 6th edn (Washington, DC: The CQ Press, 2011), 217-24. 
appearing to have sounded the death knell for authenticity in politics, The West Wing suggests that the "real" and the "fake" are still crucial distinctions.

But it is important to remember that, although mass mediation has resulted in a narrowing of the separation between reality and representation, they remain separate. Narrative fiction like The West Wing, created in the imaginations of screenwriters despite its relationship with political reality, is able to sidestep the complexities of real politics through visual and narrative choices. In its naive, nostalgic belief that an honest, individual politician could transcend the demands of the party establishment, the political system and (crucially) the media, The West Wing is not positing an ideal that could be achieved in reality, but demonstrates that there remains a yearning for a politician who seems genuine, even if he remains irretrievably fictional. Therefore, while the examples discussed in this article represent understandable responses to the crisis of authenticity in American politics, The West Wing demonstrates that the uncomplicated rearticulation of traditional conceptions of authenticity may be the only escape route available in a culture in which the practice of politics is entirely dependent on mediated construction and artifice. In such a situation, given the tendency for politicians to disappoint us (or worse), it is perhaps best that our thirst for political authenticity be quenched in fiction, allowing us to continue to view reality with the requisite scepticism and rationality.

\section{AUTHOR BIOGRAPHY}

I am an Associate Fellow in Film and Television Studies at the University of Warwick, having completed my PhD thesis in December 20I2. I am currently working on a project concerning the mediation of American monuments and memorials in visual culture. I recently published a monograph entitled The American President in Film and Television: Myth, Politics and Representation (Oxford: Peter Lang, 2014). My research interests revolve around the politics and ideologies of mainstream cinema and television, and I am currently working on a project concerning the mediation of American monuments and memorials in visual culture. 